\title{
Merit, Tenure, and Bureaucratic Behavior: Evidence from a Conjoint Experiment in the Dominican Republic
}

\author{
Virginia Oliveros ${ }^{1}$ and Christian Schuster ${ }^{2}$
}

\begin{abstract}
Bureaucratic behavior in developing countries remains poorly understood. Why do some public servants - yet not others - work hard to deliver public services, misuse state resources, and/or participate in electoral mobilization? A classic answer comes from Weber: bureaucratic structures shift behavior towards integrity, neutrality, and commitment to public service. Our paper conducts the first survey experimental test of the effects of bureaucratic structures. It does so through a conjoint experiment with public servants in the Dominican Republic. Looking at merit examinations and job stability, we find that Weber was right - but only partially. Recruitment by examination curbs corruption and political services by bureaucrats, while enhancing work motivation. Job stability, by contrast, only decreases political services: tenured bureaucrats are less likely to participate in electoral mobilization. Examinations thus enhance the quality of bureaucracy (motivation and lower corruption) and democracy (electoral competition); job stability only enhances the quality of democracy.
\end{abstract}

Forthcoming in Comparative Political Studies

Keywords: Bureaucracy; Merit; Patronage; Tenure; Conjoint Experiment; Weber

1 Tulane University
2 University College London
Corresponding Author: Christian Schuster (c.schuster@ucl.ac.uk) 


\section{Introduction}

What public servants do plays central and manifold - yet underappreciated - roles in development. To cite just three examples: how hard public servants work shapes the quantity and quality of public services citizens receive (see, e.g., Tendler, 1997; UNDP, 2014). Whether or not public servants engage in corrupt behavior alters the amount of state resources available for public service delivery, as well as the trust citizens place in government (see, e.g., Morris \& Klesner, 2010; S. Rose-Ackerman, 1999). And whether or not public servants turn out to campaign for governing parties shapes electoral playing fields and thus the fairness of elections (see, e.g., Folke, Hirano, \& Snyder, 2011; Larreguy, Olea, \& Querubin, 2014). Bureaucratic behavior thus concurrently affects the quality of public services, the quality of democratic competition, and the extent of corruption. Yet, we know surprisingly little about the determinants of bureaucratic behavior in the developing world. Why do some public servants take part in electoral mobilization, yet others do not? Why do some work hard on the job, while others do not? And why do some misuse public resources, yet others do not?

A classic answer comes from Max Weber. Weber (1978) posited that bureaucratic structures shape bureaucratic behavior. Where public servants are recruited through merit examinations, with lifelong job stability protections (tenure) and predictable promotions, and pay progression, they develop an esprit de corps around commitment to public service, political neutrality, and integrity. Competing theoretical perspectives on bureaucratic structures do exist, however. New Public Management (NPM)-inspired prescriptions, for instance, argued for fewer job stability protections and more flexible salary setting 
(Manning, 2001). ${ }^{3}$ The policy repercussions of this debate are important. The World Bank, for instance, loans US $\$ 422 \mathrm{~m}$ per year for civil service reforms, funding 277 projects between 1990 and 2013 (Blum, 2014; World Bank, 2008). Arguably, such reforms should be based on evidence about how these reforms influence the behavior of those they primarily seek to affect: public servants.

Yet, robust empirical evidence for the effects of bureaucratic structures on bureaucratic behavior in the developing world is largely lacking. A handful of cross-country and -state regressions have correlated Weberian bureaucratic structures with economic growth (Evans \& Rauch, 1999), poverty reduction (Henderson, Hulme, Jalilian, \& Phillips, 2007), lower corruption (Dahlström, Lapuente, \& Teorell, 2012a; Neshkova \& Kostadinova, 2012; Rauch \& Evans, 2000), greater infrastructure investment (Rauch, 1995), better regulation (Nistotskaya \& Cingolani, 2016), and improved health outcomes (Cingolani, Thomsson, \& de Crombrugghe, 2015). At the level of individual public servants in turn, bureaucratic structures correlate with lower corruption and clientelism (Meyer-Sahling \& Mikkelsen, 2016; Oliveros, 2016b).

How much we can learn from these studies is unclear, however. Cross-country regressions - which neglect the large inter-institutional variation of bureaucratic structures within countries - are likely to be biased (Gingerich, 2013a). Moreover, both cross-country and cross-public servant studies suffer, as observational studies, from omitted variable and reverse causality biases. Merit examinations, for instance, are likely to affect and be affected by corruption. Existing studies also mostly focus on one dependent variable at a time.

\footnotetext{
${ }^{3}$ As a caveat, note that most scholars challenge the utility of NPM prescriptions in developing countries (Manning, 2001).
} 
Arguably, however, the desirability of bureaucratic structures depends on their concurrent effects on the political and administrative behavior of public servants.

To address these shortcomings, this paper conducts the, to our knowledge, first survey experimental test of the effects of bureaucratic structures. We focus on two key aspects of Weberian states (merit examinations and tenure protections) and assess their effects on three central dimensions of bureaucratic behavior and attitudes in developing countries: corruption, clientelism, and work motivation.

Our experimental design - a conjoint survey experiment - is the first application of this method to the study of bureaucracy; it thus also responds to the manifold recent calls to expand and innovate on the experimental study of bureaucracy (e.g. James, Jilke, \& Van Ryzin, 2017). We conducted this survey experiment with a population which remains understudied by scholars: government employees in highly politicized states, in our case 558 career public servants in the Dominican Republic. We find that merit examinations affect all three studied dimensions of bureaucratic behavior favorably: they are associated with fewer political services (clientelism), lower corruption, and greater work motivation of public employees. Substantively, the effects on political services and corruption are largest, with a less strong effect on work motivation. The primary benefit of examinations in politicized states thus appears to be not a more hard-working civil service, but a less clientelistic and corrupt one, with fewer public employees campaigning for parties or misusing state resources. The effect of bureaucratic job stability, by contrast, is limited to curbing political services: public servants protected from dismissal are less likely to participate in electoral mobilization. By contrast, job stability is not robustly associated with work motivation and corruption. 
Our findings thus confirm most - albeit not all - of Weber's predictions. Merit examinations, indeed, contributes to a public service which works with greater integrity, motivation, and political neutrality. Job stability protections, by contrast, only deliver on one of Weber's promises: a more politically neutral public service, which is less willing to help with electoral efforts. Somewhat ironically, introducing tenure thus appears to be principally a means to improve the quality of electoral competition, not bureaucratic work motivation or integrity. For the manifold civil service reform attempts in developing countries, this is welcome news: changing bureaucratic structures can shift bureaucratic behavior in developing states for the better. Governance practitioners should thus take Weber to heart.

\section{Merit Examinations, Tenure, and Bureaucratic Behavior}

A growing number of scholarly works sheds light on bureaucracies in developing countries (see, among many, Fukuyama, 2014; Grindle, 2012; Rothstein, 2011). For our purposes, this body of research has usefully illustrated the diversity of bureaucratic structures. In particular, countries and state institutions within them vary in regards to whether they recruit their public employees through merit examinations (merit) or discretionary appointments; and whether they provide them with job stability protections (tenure) or maintain discretion over dismissals (Gingerich, 2013b; Rauch \& Evans, 2000). ${ }^{4}$ Yet, how variation in merit and tenure affects the behavior of public servants in developing countries remains scantly studied.

\footnotetext{
${ }^{4}$ Note that merit and tenure need not - and frequently do not - coincide in developing countries (Dahlström, Lapuente, \& Teorell, 2012b; Schuster, 2016a).
} 
In regards to our first dimension of bureaucratic behavior - corruption ${ }^{5}$ - most of the extant literature is of little avail: it focuses on incentive structures and behavior of political elites. ${ }^{6}$ The relationship between corruption and our bureaucratic structures of interest, however, has received a lot less attention in the literature.

Recruitment through examinations rather than by discretionary appointment has been associated with lower corruption in at least four studies (Charron, Dahlström, Fazekas, \& Lapuente, 2017; Dahlström et al., 2012a; Meyer-Sahling \& Mikkelsen, 2016; Rauch \& Evans, 2000). Drawing on cross-country expert-survey data, Rauch and Evans (2000) and Dahlström, Lapuente and Teorell (2012a) find that the level of meritocratic recruitment correlates with lower corruption. Meyer-Sahling and Mikkelsen (2016) identify the same effect in surveys of public employees in post-communist countries, as do Charron et al. (2017) for corruption risks in public procurement in European regions, albeit with a measure that approximates merit promotions rather than recruitment. Theoretically, this relationship is plausible, even if evidence on the (competing) underlying mechanisms is missing to-date. Public servants recruited through examinations may be more likely to develop an esprit de corps, a professional bureaucracy with "greater adherence to norms of behavior" of integrity (Rauch \& Evans, 2000, p. 52). Alternatively, merit recruitment may curb corruption by creating a "separation of interests:" a professional bureaucracy-in which employees are recruited based on merit and not political criteria- will have different interests from politicians, which facilitates checks and balances (Dahlström et al., 2012a).

\footnotetext{
${ }^{5}$ In this paper we define corruption as the abuse of public office or state resources for personal or political gain (see, among many, Gingerich, 2013b, p. 10 for a similar definition).

${ }^{6}$ Scholars have sought to explain varying levels of corruption by looking at electoral systems (e.g. Gingerich, 2013b), information (e.g. Winters \& Weitz-Shapiro, 2013), and electoral competition (e.g. Grzymala-Busse, 2007), to mention a few examples (see Treisman, 2007 for a review of this literature).
} 
Based on the existing evidence and the mechanisms outlined, we expect to find a positive effect of meritocracy on curbing corruption.

Hypothesis 1 (H1): Public employees recruited through examinations will be less likely to engage in corrupt behavior.

Empirically and theoretically, the relationship between bureaucratic job stability and corruption is less clear-cut. Neither Rauch and Evans (2000) nor Dahlström et al. (2012a) find significant correlations in their studies. Theoretically, however, we could expect tenure to affect corruption. If the esprit de corps hypothesis held, tenure should facilitate long-term socialization into a public service ethos which should curb corruption (Dahlström et al., 2012a). Moreover, long time horizons guaranteed by the tenure system should reduce the relative attractiveness of quick returns from corruption (see, classically, Becker \& Stigler, 1974). Finally, a tenure system should also help protect (honest) bureaucrats from corrupt politicians pressuring bureaucrats to help them in corrupt enterprises. For these reasons, we expect to find a positive effect of tenure on curbing corruption.

Hypothesis 2 (H2): Public employees with job stability protections will be less likely to engage in corrupt behavior.

Alternatively, however, the tenure system could also help protect corrupt bureaucrats from (honest) politicians. To fire a corrupt employee whose tenure is protected, an illegal act needs to be proven. Since acts of corruption are particularly hard to prove, the tenure system could also shelter potentially corrupt employees. We propose then an alternative hypothesis to $\mathrm{H} 2$. 
Hypothesis 2' (H2'): Public employees with job stability protections will be more likely to engage in corrupt behavior.

The effects of merit and tenure on our second dimension of bureaucratic behavior clientelism - has been even more rarely studied. The literature on clientelism in public employment is, of course, vast (see, e.g., Calvo \& Murillo, 2004; Grzymala-Busse, 2007; 0'Dwyer, 2006). Yet, to our knowledge, no prior study has directly assessed the effect of merit examinations on clientelism; and only one study correlates tenure with relatively (less) political services (Oliveros, 2016b). This omission is remarkable given the centrality of bureaucrats in clientelist exchanges, and the centrality of clientelism in the functioning of new democracies (Grzymala-Busse, 2007; 0'Dwyer, 2006).

In this paper, we provide empirical evidence for the effects of bureaucratic structures on the bureaucrats' side of patron-client bargains: the provision of political support or services to help (governing) parties' or politicians' electoral fortunes. Such support often involves helping with electoral mobilization, attending rallies or campaign events, monitoring elections, and transforming public services and administrative procedures into clientelistic exchanges (Oliveros, 2016a, 2016b; Stokes, Dunning, Nazareno, \& Brusco, 2013; WeitzShapiro, 2014; Zarazaga, 2014).7 In clientelist agreements, political patrons may reciprocate such services with goods or favors for bureaucrats - including jobs, pay rises, promotions, favorable transfers, and protection from dismissal. ${ }^{8}$

\footnotetext{
${ }^{7}$ In higher-level positions, political support can also equate to ensuring that lower-level employees and state resources are fully used to support political patrons (see, e.g., Geddes, 1996; Gingerich, 2013b).

8 We thus understand clientelism as a personalized and discretionary exchange of goods or favors for political support (see, e.g., Stokes et al. (2013, p. 6-18) for a similar definition).
} 
We expect both merit examinations and job stability to curb political service provision by bureaucrats. Merit examinations preclude discretionary appointments to the public sector, and thus deprive political patrons of one important good to trade in exchange for political services: jobs. ${ }^{9}$ Since employees do not owe their positions to a political patron, there is no explicit or implicit understanding for the provision of political services in return for recruitment into the public sector (see, among many, Geddes, 1996; Oliveros, 2016b).10 For this reason, we expect that merit examinations will have a negative effect on the provision of political services, such as helping with electoral mobilization or attending a campaign event.

Hypothesis 3 (H3): Public employees recruited through examinations will be less likely to provide political services.

For tenure protections, we expect a similar effect. Prior studies point to two underlying mechanisms. First, with job stability, public sector jobs are not anymore a "reversible method of redistribution" (Robinson \& Verdier, 2013, p. 261): dismissals are not anymore a credible threat that politicians can use to make bureaucrats provide political support. In this way, tenure provisions protect employees from political pressures to participate in electoral mobilization. ${ }^{11}$ Second, irrespective of this threat of dismissal, nontenured employees might be more inclined to provide political services because they might

\footnotetext{
${ }^{9}$ This particular exchange is sometimes termed patronage (see, for instance, Stokes, 2007). Other scholars, however, equate patronage with clientelism (e.g. Kitschelt \& Wilkinson, 2007a) and, still others equate it with discretionary appointments to public sector positions (e.g. Grindle, 2012). For our purposes, it suffices to note that public jobs are a central, albeit not the only, good patrons can offer in exchange of political services.

${ }_{10}$ Public employees may still provide political services in exchange for other goods or promises from patrons, such as pay rises or protection from dismissal.

${ }^{11}$ The fear of losing their job (either because of getting fired by the incumbent administration or a new one) is not the only fear that public employees hold. Even tenured employees might fear being demoted, transferred, or sidestepped, for instance (Oliveros, 2016b).
} 
fear losing their jobs with a change in the administration. Indeed, in at least one study, untenured employees who more closely identified with the incumbent are more likely to provide political services to help the incumbent stay in power because they are afraid of losing their jobs with a change of administration (Oliveros, 2016b).12

Hypothesis 4 (H4): Public employees with job stability protections will be less likely to provide political services.

Finally, in regards to our third dimension - work motivation - the empirical literature on bureaucratic structures in developing countries is, to our knowledge, largely mute. This reflects a more general dearth of studies examining the work motivation of civil servants in developing countries (Tendler, 1997). ${ }^{13}$ First, examinations could, theoretically, be expected to both increase and decrease work motivation. Ideally, political appointees would be characterized by "responsive competence" (Moe, 1985, p. 244). Owing their positions to political patrons, they are responsive to the needs of authorities and thus, arguably, more willing to work hard to deliver results for them.

Hypothesis 5 (H5): Public employees recruited through examinations will be less motivated to work.

\footnotetext{
${ }^{12} \mathrm{~A}$ competing prediction arises if insights from the literature on reciprocal patron-client relations are taken at face value. This literature suggests that feelings of reciprocity, rather than self-interest, monitoring or punishment, are at the core of clientelistic exchanges (Finan \& Schechter, 2012; Lawson \& Greene, 2014). From this perspective, one would expect that employees with job stability would be more willing to reciprocate their tenure contracts with more political services, instead of less. Most studies of clientelism, however, take instrumental views, and no prior studies have studied reciprocity effects within bureaucracies to our knowledge.

${ }^{13}$ A range of studies has examined public service motivation - "an orientation to delivering services to people with a purpose to do good for others and society" - in developing countries (e.g. Houston, 2014; Kim et al., 2013 , p. 80). Yet, to our knowledge, work motivation - the willingness to work hard and work well - has not been studied.
} 
At the same time, however - and contrary to Moe's (1985, p. 244) ideal responsiveness may come at the cost of competence. Employees selected through open, merit-based competitions with (large) applicant pools are likely to feature greater professional competence. As such, they are also more likely to develop professional norms which in turn are associated with greater motivation and performance (see, e.g., Andersen, 2009). Regrettably, empirical evidence which resolves these competing predictions is unavailable. ${ }^{14}$ Our study is the first to fill this lacuna. We therefore propose an alternative hypothesis to $\mathrm{H} 5$.

Hypothesis 5' (H5'): Public employees recruited through examinations will be more motivated to work.

The literature on job stability protections, similarly, offers competing predictions. Tenure facilitates socialization into Weber's (1978) public service ethos, which in turn could be expected to enhance work commitment and motivation. Moreover, job security enhances employee feelings of safety and thus of working in a supportive working environment which could equally enhance their work motivation. Consistent with these mechanisms, tenure has been associated with greater work motivation in civil services in several OECD countries as well as in social services - such as for medical personnel - in developing countries (Buelens \& Van den Broeck, 2007; Willis-Shattuck et al., 2008).

Hypothesis 6 (H6): Public employees with job stability protections will be more motivated to work.

\footnotetext{
${ }_{14}$ Political appointees have been associated with lower performance outcomes in the U.S. bureaucracy literature (Gallo \& Lewis, 2012; Lewis, 2007). This does not remedy the lack of evidence on work motivation, however: more responsive (but less competent) appointees could be more motivated to work, yet still achieve worse performance outcomes.
} 
Tenure protections, however, also deprive managers of an important sanction for unmotivated, non-performing employees; and in some sectors - such as academia - tenure can correlate with lower productivity (and thus, arguably, work motivation) (see, classically, Holley, 1977).

Hypothesis 6' (H6'): Public employees with job stability protections will be less motivated to work.

\section{Research Design}

To isolate the effects of bureaucratic structures, we employ a conjoint survey experiment. In the experiment, we ask respondents to choose between pairs of hypothetical colleagues in the public sector, randomly varying several of the colleagues' characteristics. To our knowledge, this is the first application of conjoint experiments to study bureaucracy and bureaucrats. Conjoints have recently seen uptake in political science, with studies in areas such as attitudes towards immigration (Hainmueller \& Hopkins, 2015) and election of working class candidates (Carnes \& Lupu, 2016). Beyond its empirical contributions, this paper also demonstrates that this method can be usefully adapted to the study of bureaucracy.

Conjoint experiments are particularly suited for our purpose: they allow us to identify, measure, and compare the independent effects of various characteristics in a single experiment (Hainmueller, Hopkins, \& Yamamoto, 2014). This is achieved through a choicebased design in which respondents are asked to choose between hypothetical profiles with randomly varying attribute values. In our specific adaptation to the study of bureaucratic 
behavior, we ask public servants to choose between pairs of hypothetical colleagues in the public sector, randomly varying several of the colleagues' characteristics - including how they were recruited and whether they enjoy job stability.

This technique offers several methodological advantages over regular surveys with direct elicitation of responses and over other types of survey experiments. To begin with, randomization of attributes addresses concerns with omitted variable and reverse causality biases in observational studies. Moreover, conjoint experiments reduce problems of social desirability bias in multiple ways. Respondents are provided with multiple reasons to justify any particular choice (Hainmueller et al., 2014). Choices also do not require assessments of absolute levels of corruption, political services, or work motivation - only relative assessments of two choices. Third, contrary to other survey experiment techniques, conjoint experiments allow us to estimate the effects of different attributes simultaneously. To illustrate, in our application, we can simultaneously assess the independent effects of gender, education, form of recruitment, job stability, seniority, and position on the perception of respondents on, for instance, how easily these employees could be convinced to attend a campaign event. Finally, choices presented in conjoint designs often involve trade-offs between preferences for different characteristics, offering greater realism than the direct elicitation of preferences on one dimension (Hainmueller et al., 2014). In part as a result, conjoints also perform more strongly than other experiments in terms of their external validity (Hainmueller, Hangartner, \& Yamamoto, 2015).

Our choice to use a conjoint experiment comes, however, with an important downside: our outcome variables are perception-based. Measuring perceptions of bureaucratic behavior is, of course, not the same as measuring actual bureaucratic behavior. Yet, a broad 
literature contends that perception-based measures can be useful to study issues as diverse as policy and ideological positions of parties and politicians (e.g., Murillo, Oliveros, \& Vaishnav, 2010; Wiesehomeier \& Benoit, 2009), corruption (e.g. Anderson \& Tverdova, 2003; Davis, Camp, \& Coleman, 2004), and clientelism (Kitschelt \& Kselman, 2013). Our particular perception-based measures of corruption, clientelism, and work motivation approximate expert surveys-a useful technique to measure complex or difficult to observe variables (Wiesehomeier \& Benoit, 2009). ${ }^{15}$ Our conjoint experiment resembles an expert survey approach in the sense that we are asking our respondents to report their perceptions on others, in our case colleagues with certain attributes. Relative to other expert surveys, however, our respondents interact with colleagues with the characteristics we are studying here on a daily basis and are thus much more likely and able to base their responses on firsthand knowledge of the outcomes. As a result, it is plausible to expect that the way our respondents perceive hypothetical colleagues to be more or less inclined towards hard work, integrity, and political neutrality to be based on the respondents' personal experiences with colleagues with similar characteristics. ${ }^{16}$

\subsection{Case selection}

Our case selection rationale was three-fold. To get leverage on the effect of bureaucratic structures on bureaucratic behavior, we sought a case in which bureaucratic clientelism and

\footnotetext{
15 Indeed, prior studies do suggest that expert surveys can provide important insights into bureaucratic behavior, including patronage and clientelism (Kitschelt \& Wilkinson, 2007b; Kopecký, Mair, \& Spirova, 2012). 16 Bureaucratic behavior, of course, need not be studied based on perceptions. Inventive measures of bureaucratic behavior are offered in recent works (see, e.g., Charron et al., 2017; Weitz-Shapiro, 2014). These original measurement solutions come, however, with an important downside for our purpose: they typically measure only one outcome at a time. Our objective, by contrast, was to measure three outcomes of bureaucratic structures simultaneously - work motivation, corruption, and clientelism.
} 
corruption are sufficiently widespread to be observable by bureaucrats; and in which merit and tenure vary within state institutions. To enhance confidence in the generalizability of our findings, we, in addition, sought a "less likely" case, which was biased against an effect of Weberian bureaucratic structures on bureaucratic behavior. With this rationale, we selected the central government in the Dominican Republic (DR).

Clientelism and corruption are widespread in the DR's central government. The DR ranks as the third most clientelist state in the world according to an expert survey in 88 countries (Kitschelt, 2014); and the most clientelist country in Latin America (AmericasBarometer, 2014). It also ranks high in bureaucratic corruption, scoring 0.81 in the Varieties of Democracy (V-Dem) Public Sector Corruption Index - a measure of bribery and embezzlement of public funds by public employees (Coppedge et al., 2017). The score puts the DR close to the countries with the highest bureaucratic corruption worldwide. ${ }^{17}$

In this context, political discretion has historically been the rule of the game in civil service management, from recruitment to promotion, pay and dismissal (Schuster, 2016b). In fact, according to an expert survey in 179 policy areas in 22 countries (Kopecky et al., 2016), the DR features the state with the greatest range and depth of party patronage. At the same time, in this politicized context, incremental Weberian reforms - merit examinations and bureaucratic tenure protections - have occurred in the last two decades (Schuster, 2014). Our survey design exploits the resulting variation in bureaucratic structures within state institutions. Since 2004, merit examinations for administrative personnel had been introduced for over 3,000 positions in the central government (roughly two percent of total

\footnotetext{
17 Where the DR stands globally in terms of work motivation remains, unfortunately, unclear, as global public
} sector work motivation data comprising the DR does, to our knowledge, not exist. 
vacancies). ${ }^{18} \mathrm{~A}$ wide range of state institutions - 65 in total - recruited select personnel through merit examinations. The remaining vacancies were filled through political appointments. At the same time, a total of 33,395 public servants (seven percent of total employees) have been incorporated into an "administrative career" since 1995. While career paths for these employees remain undefined, a 2008 public service law and a 2010 constitutional reform granted them tenure protection.

While offering variation in merit and tenure, the DR's context is biased against finding an effect of them. Enforcement of bureaucratic structures - in particular tenure protections - is partial, curtailing their effect on bureaucratic behavior. Governing parties appoint to audit institutions and the judiciary, thus controlling the key institutions safeguarding tenure enforcement. Hence, career servants face uncertainty about the extent to which their constitutional tenure rights will be protected. As a result, as detailed below, only just over half of them associate greater job stability with their tenure protections. Moreover, political patrons still have discretionary power over pay rises, promotions, and transfers, with which to incentivize the behavior of public servants, even when these are legally tenured and/or recruited based on merit.

These contextual features of the DR case are, of course, not unique. Many countries with politicized bureaucracies also feature weak legal enforcement (Charron, Dahlström, \& Lapuente, 2012). In this sense, the conclusions we draw from the DR case may plausibly travel to the range of countries with politicized bureaucracies. In a recent global expert survey, 64 percent of non-OECD countries fell into this category, with political criteria

\footnotetext{
18 Merit examinations were more prevalent for non-administrative personnel. Almost 24,000 teachers were recruited through merit examinations in 2006-2012, for instance (Schuster, 2016b).
} 
trumping merit in public sector recruitment (Dahlberg, Dahlström, Sundin, \& Teorell, 2013). ${ }^{19}$

Despite their ubiquity, though, public servants in hyper-politicized administrations such as the DR's remain scarcely studied. This is, arguably, an important omission. Bureaucrats in hyper-politicized states can play important roles in tilting elections in favor of governments by campaigning for incumbents, channeling state resources to party supporters, depriving the public of resources for private enrichment and, at times, seeking to deliver quality public services despite politicization pressures (Gingerich, 2013b; Grzymala-Busse, 2007; Oliveros, 2016a, 2016b; Tendler, 1997; Weitz-Shapiro, 2014). Shedding new light on bureaucratic behavior in such contexts is thus an important empirical contribution of this paper in its own right.

\subsection{Survey Frame and Sample}

Our data come from an online survey of central government employees in the Dominican Republic administered through Qualtrics between November 2015 and January 2016. The Ministry of Public Administration provided the survey frame for the convenience sample. ${ }^{20}$ The Ministry held a database of email addresses and observable characteristics age, gender, institution, and seniority - of 2,416 administrative career public employees in

\footnotetext{
19 This is not to say that our findings may not have relevance for countries with more professionalized bureaucracies. Bureaucratic politicization at the top does occur in professionalized bureaucracies, and can shape bureaucratic outcomes (Gallo \& Lewis, 2012). Whether our findings are generalizable to such contexts thus remains an important area for further empirical inquiry.

${ }^{20}$ In the Dominican central government, respondents would, ideally, be randomly sampled. The very nature of politicized states, however, precludes studying them with random samples: poor formal monitoring mechanisms implies politicized governments like the DR's typically lack accurate lists of employees working for them (see, for instance, Dumas \& Lafuente, 2015).
} 
the central government. This database included all employees who, when registering as an administrative career servant with the Ministry of Public Administration, had provided an email address as part of their contact details. Of the 2,416 email addresses, 1,993 were working. All were sent an electronic invitation and three reminders to participate. 725 career servants started completing the online survey; 558 respondents - our sample - completed at least one conjoint experiment response. The response rate for our purposes was thus $28 \% .{ }^{21}$

Respondents are representative of the general population of central government employees in terms of age and sex (Table A1 in Online Appendix (OA)), but, on average, more educated and more likely to be in professional ranks in the administrative hierarchy (Table A2 in OA). They came from 24 different state institutions (Table A3 in OA).

\subsection{Conjoint experiment}

Our experiment asked respondents to choose between profiles of two hypothetical public employees for a number of activities. We randomly vary the two employees' profiles on six attributes: year of appointment, form of recruitment, administrative career (tenure), education, position, and gender (Table 1).22 The order of the attributes was randomized across respondents to rule out primacy effects, but was fixed across pairings for each respondent to reduce complexity (Hainmueller \& Hopkins, 2015).

\footnotetext{
${ }^{21}$ This number is slightly lower for conjoint questions 2-5.

${ }^{22}$ Two restrictions were imposed on the randomization to exclude combinations which would have been implausible to respondents: professional-level public employees with secondary education, either hired through examination and/or incorporated into the administrative career.
} 


\section{Table 1: Attributes and Attributes Values for Profiles in Conjoint Experiment}

\begin{tabular}{ll} 
Attributes & Values \\
\hline Year of Appointment & 2002 (Mejía Presidency) \\
& 2005 (Fernández Presidency) \\
& 2013 (Medina Presidency) \\
& Public examination \\
Recruitment & Appointment \\
Administrative Career & Incorporated \\
& In process of incorporation \\
& Not incorporated \\
Education & High School \\
& College Degree \\
Position & Administrative Support \\
& Technical- Professional \\
Sex & Female \\
& Male \\
\hline
\end{tabular}

Each respondent evaluated, on separate screens, five pairs of randomly generated profiles. ${ }^{23}$ Following a short introduction, we show respondents a screen with the profiles of two hypothetical employees as illustrated in Figure 1. In the instructions to respondents, these were presented as two "public employees from the central government." The profile comparisons were followed by several questions - our dependent variables - which require respondents to choose between the two employees for different activities. ${ }^{24}$ The question order was randomized at the level of respondents to minimize priming effects.

\footnotetext{
${ }^{23}$ This enhances estimate precision without risking reliability: other studies point to no loss in reliability in forced choice conjoints with ten or fewer tasks (Hainmueller et al., 2015; Johnson \& Orme, 1996). Our diagnostic check below confirms reliability across tasks for our own survey.

${ }^{24}$ The experiment included five questions. In this paper, we focus on three of those.
} 


\section{Figure 1: Example Profile Comparison}

\section{Encuesta a los Servidores de la Carrera Administrativa}

Por último, se presentan a continuación cinco comparaciones de dos perfiles de servidores públicos del gobierno central. Para cada una de las comparaciones, por favor responda las preguntas pertinentes.

Comparación $1 / 5$

\begin{tabular}{|c|c|c|}
\hline & Empleado 1 & Empleado 2 \\
\hline Año de Ingreso & 2005 (Presidencia de Fernández) & 2013 (Presidencia de Medina) \\
\hline Forma de Ingreso & Nombramiento & Nombramiento \\
\hline Carrera Administrativa & En Proceso de Incorporación & No Incorporado \\
\hline Nivel Educativo & Secundario & Licenciatura \\
\hline Puesto & Apoyo Administrativo & Técnico/Profesional \\
\hline Sexo & Femenino & Masculino \\
\hline
\end{tabular}

The dependent variable questions measure corruption, political services, and work motivation. The first question is a proxy measure for Corruption: "Which of the two would you trust to administer the funds of a project transparently?" This is, of course, an indirect measure of corruption. A more direct question of corruption was precluded by the need for government authorization of the survey. While we acknowledge that the lack of transparency does not necessarily imply corruption, the lack of transparency is indeed a precondition for corruption. Since acts of corruption are harder to detect, lower levels of transparency in the public administration may lead to higher levels of corruption. This relationship between transparency and corruption has been asserted in a range of studies (see, e.g., Gerring \& Thacker, 2004, pp. 316-317; Montinola \& Jackman, 2002, p. 151), and has recently seen empirical support in several works (see, e.g., Kaufmann, Mastruzzi, \& 
Zavaleta, 2003; Lindstedt \& Naurin, 2010; Peisakhin, 2012). ${ }^{25}$ At the same time, our measure focuses not on transparency in general, but the transparent administration of project funds. Lack of transparency in fund management is a prerequisite for misusing funds. We may thus plausibly expect respondents to associate this question also with the misuse of funds.

The second question is a measure for Political Services: "Which of the two would you find easier to convince to come to an electoral campaign event?" The question refers to the bureaucrats' side of patron-client arrangements: the provision of political services or support to help politicians' electoral fortunes. Here we focus on one of the most common of these political services among low and mid-level employees: participation in a campaign event. ${ }^{26}$

Finally, the third question measures Work Motivation: "Which of the two would you find easier to motivate to work some extra hours to get a pending job done?" The phrasing of the question closely mirrors commonly used work motivation measures in the U.S. Office of Personnel Management's (2016) Federal Viewpoint Survey ${ }^{27}$ and in Wright (2004) ${ }^{28}$. Drawing on a single measure of work motivation, our study cannot offer insights into different dimensions of work motivation (cf. Wright, 2004). However, it does shed light on our core concern: public employees' desire to work hard and work well in their jobs.

\footnotetext{
${ }^{25}$ For an overview of the empirical literature of the relationship between corruption and transparency, see Rose-Ackerman (2004, p. 316-322).

${ }^{26}$ In the DR, 38 percent of public employees admit to working in electoral campaigns in population surveys, relative to 15 percent of respondents outside the public sector (Espinal, Morgan, \& Seligson, 2012). In the DR's hyper-presidentialist system, campaigning by public servants largely implicates campaigning for the governing party. To illustrate, during the 2008 elections, 13 out of 16 ministries were publicly incorporated into the PLD campaign command (Participación Ciudadana, 2008).

27 'When needed I am willing to put in the extra effort to get a job done.'

28 'I am willing to start work early or stay late to finish a job.'
} 
In regards to our explanatory variables, we are, most of all, interested in the Recruitment and Administrative Career (Tenure Protection) attributes. Our Recruitment variable randomly takes on two values: examination or appointment. Administrative Career, in turn, takes on one of three values: "Incorporated", "In process of incorporation", and "Not incorporated". Public servants incorporated into the administrative career enjoy tenure protections, while those not incorporated or in the process of incorporation do not. At the same time, public servants in the process of incorporation resemble career servants with tenure in observable and unobservable characteristics. They meet the formal (education and seniority) and informal (high-level political acquiescence) eligibility criteria for career entry (Schuster, 2014). Yet, the paperwork for career entry - and thus attainment of job stability can take up to a year. ${ }^{29}$

Finally, we also randomly vary other attributes that previous studies identify as potentially influential for our outcomes of interest: year of appointment, education, position, and sex. For instance, previous studies have shown that women tend to be generally less involved in corruption than men and less likely to tolerate corruption (Swamy, Knack, Lee, \& Azfar, 2001; Torgler \& Valev, 2010); and, at least in one study, more willing to provide favors to voters (Oliveros, 2016a). Similarly, the year of appointment might have an effect on our outcomes. In a politicized state like the DR, the recruiting Presidency might be perceived as a proxy for the political sympathies of the employee. For instance, employees ideologically closer to the party in power (appointed by the current administration) might be more willing to provide political services to the politician that had hired them (Oliveros, 2016b). Finally,

\footnotetext{
${ }^{29}$ As a result, we can isolate the effect of job stability from confounding associations respondents may have about unique characteristics of administrative career servants by comparing public servants incorporated into the career with those in the process of incorporation (cf. Dafoe, Zhang, \& Caughey, 2015).
} 
more educated employees might be expected to behave differently from less educated colleagues since they enjoy better labor market opportunities in the private sector (Calvo \& Murillo, 2004).

\section{Results}

What effects do Weberian state structures have on bureaucratic behavior in the Dominican Republic? To find out, we estimated linear probability models relating our dependent variables to varying values of our six attributes: recruitment, administrative career (tenure), position, education, gender, and year of appointment..$^{30}$ As respondents were presented with five successive profile comparisons, standard errors were clustered by respondent (see Hainmueller et al., 2014 for further detail on the empirical analysis of conjoint experiments). ${ }^{31}$

Figures 2 to 4 plot the results for our outcome variables: corruption, political services, and work motivation. ${ }^{32}$ Point estimates for each attribute value represent their average marginal component effect (AMCE) over baseline values, along with 95 percent confidence intervals. To illustrate with an example, an AMCE is the difference in probability that a respondent would find a public servant recruited via examination easier to convince to work hard relative to an otherwise identical public servant recruited via appointment.

\footnotetext{
${ }^{30}$ Estimates were calculated using the 'cjoint' package in R (Strezhnev, Berwick, Hainmueller, Hopkins, \& Yamamoto, 2016).

31 Our experimental design is robust to the range of diagnostic checks laid out in Hainmueller et al. (2014). We find neither significant profile order, attribute order or carryover effects for merit and tenure. We estimate these by testing whether the number of significant differences between all possible pairwise comparisons of estimates for recruitment and job stability between left-right profiles, top-to-bottom-attributes and first-tolast task are larger than those resulting from a random draw. We find no statistically significant profile order effects (at the 5\% level) for recruitment and job stability for each of our three dependent variables. For attribute order and task order (carryover), the number of significant differences between pairwise comparisons of estimates is not significantly larger than the number which would be expected to result from a random draw. ${ }^{32}$ The full regression models for these figures are displayed in Tables B.1-B.3 in the Online Appendix.
} 
For our first dimension of bureaucratic behavior, corruption, bureaucratic structures make a difference - albeit in a heterogeneous manner (Figure 2). In line with our theoretical expectation (H1), respondents are significantly more trusting of employees recruited through examination when it comes to non-corrupt management of funds $(+10 \%)$. At first sight, the same appears to hold for employees with job stability (H2): public servants in the administrative career (with tenure) are significantly more likely ( $+16 \%$ ) to be trusted with the non-corrupt management of funds than those not incorporated. Note, however, that respondents may associate characteristics other than job stability with public servants incorporated into the career - such as greater skill or closer relationships with supervisors. As a robustness check which addresses the resulting confounding concern (Dafoe et al., 2015), we thus also compare public servants inside the career with those in the process of career incorporation (with similar unobservable characteristics, but no tenure). In the case of corruption, the estimate for administrative career servants $(+16 \%)$ is significantly larger than that of public servants who are in the process of incorporation $(+5 \%)$. Job stability thus appears to reduce perceived corruption. As detailed below, however, this result is not robust.

Estimates for the other attributes predict sensible differences. Respondents place greater trust in public servants to manage project funds in a transparent manner when they are more educated, female, and at the technical-professional level. This is consistent with prior studies on gender and corruption (Frank, Lambsdorff, \& Boehm, 2011; Swamy et al., 2001; Torgler \& Valev, 2010), and several studies of education and corruption (e.g. Botero, Ponce, \& Shleifer, 2013; but see Winters \& Weitz-Shapiro, 2013). In addition, employees recruited by the incumbent party Presidents (Fernández and Medina) - rather than by the opposition - are also perceived to be less corrupt. This may appear to run counter to 
responsiveness arguments: public servants recruited by the governing party may be more inclined to engage in "stealing for the team" (Gingerich, 2013b). In the Dominican context, however, our findings are highly plausible since the Mejía administration (2000-04) was recognized as one of the most corrupt in recent Dominican history (Singer, 2012).33

Figure 2. (Lack of) Corruption

Recruitment Modality:
Appointment
Examination
Tenure Protection:
No
In Process of Incorporation
Yes
Position:
Administrative Support
Technical-Professional
Education Level:
High School
University Degree
Year of Appointment:
2002 (Mejia Presidency)
2005 (Fernandez Presidency)
2013 (Medina Presidency)
Gender:
Male
Female

\section{Figure 2. (Lack of Corruption}


For our second dimension of bureaucratic behavior - political services - the effects of bureaucratic structures confirm our theoretical expectations (Figure 3). Respondents are significantly less likely to find public servants recruited via examination easier to convince to attend an electoral campaign event (-12\%) (H3). Vice versa, this suggests that appointees are found significantly easier to mobilize for electoral campaigns. This effect of examinations on political services is, substantively, almost twice as large as the effect on work motivation discussed further below. Similarly, job stability exerts a significant (and negative) perceived effect on political services (H4). Estimates for public servants in the administrative career ($8 \%)$, yet not for those in the process of career incorporation $(-3 \%, \mathrm{p}=0.14)$ are significant. ${ }^{34}$ Respondents thus find public servants with job stability harder to mobilize for electoral campaign events. A second identification strategy in the 'robustness checks' section below confirms this finding.

The other characteristics, once again, predict sensible differences. Our respondents are significantly more likely to find public employees easier to convince to attend electoral campaign events when they are recruited by the incumbent party Presidents, less educated, and at lower hierarchical ranks. ${ }^{35}$ This is consistent with the handful of studies on bureaucratic behavior in politicized states: educated and professional employees with better private labor market alternatives (Calvo \& Murillo, 2004), and employees not hired by the incumbent party may face fewer incentives to participate in electoral mobilization (Oliveros, 2016b).

\footnotetext{
34 The estimate for public servants in the process of career incorporation is significantly smaller than that of career public servants at the $10 \%$ level $(\mathrm{p}=0.099)$.

35 The effect of technical-professional positions is not statistically significant, however $(\mathrm{p}=0.11)$.
} 
Respondents also find it harder to mobilize female colleagues to campaign. To-date, there is virtually no research on the role of gender in bureaucratic clientelism (but see Oliveros, 2016a). This is surprising not least in view of the significant body of research on gender and corruption (Swamy et. al, 2001; Torgler \& Valev, 2010). In fact, to our knowledge, our study is the first to link female bureaucrats with a significant negative effect on political service provision to incumbents. ${ }^{36}$

Figure 3. Political Services
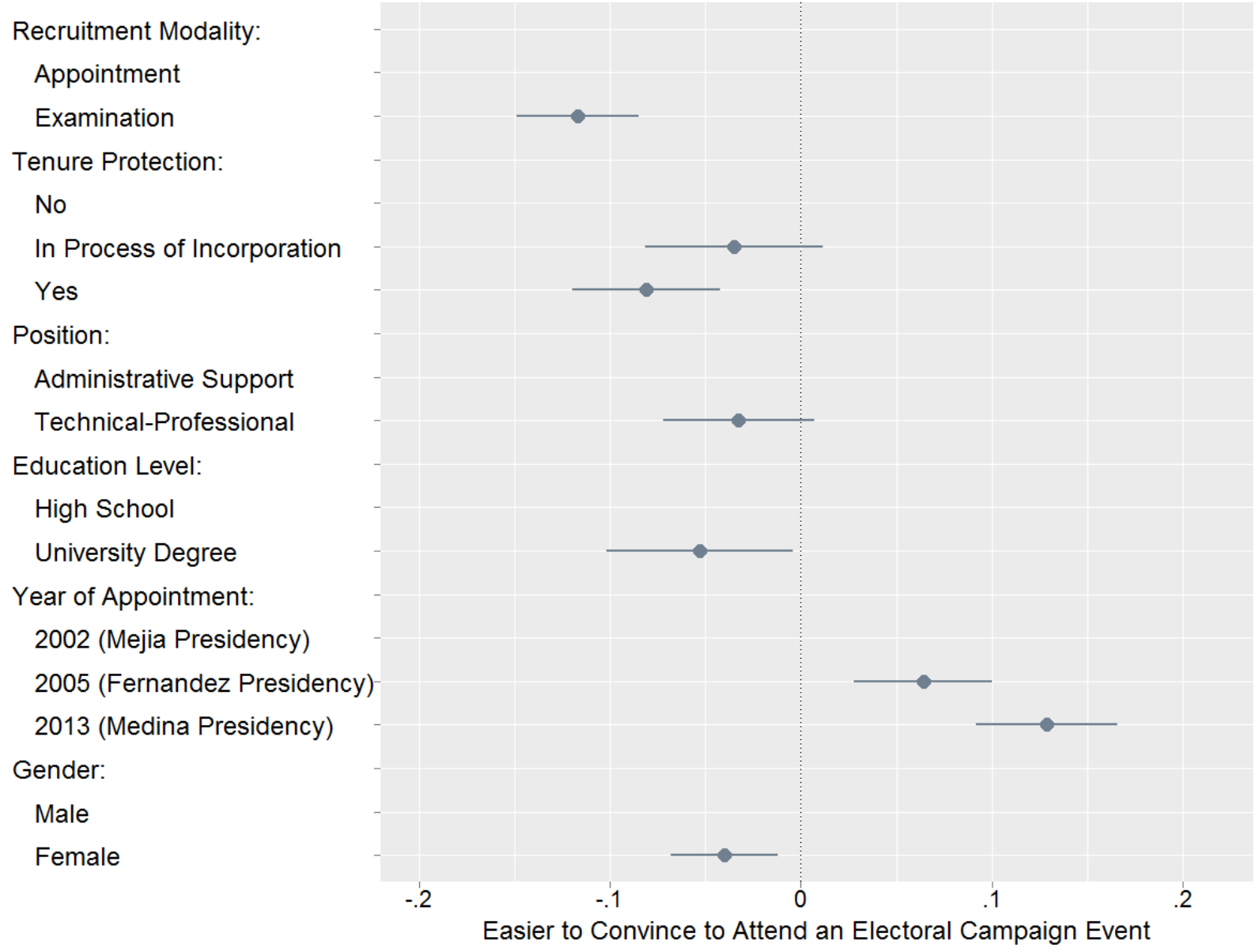

\footnotetext{
${ }^{36}$ Note that this effect does not stem from female respondents preferring their own group of fellow female public servants. Both male and female respondents find women to be less willing to provide political services and less corrupt (see Figures 5.a and 5.b in OA).
} 
Finally, when it comes to our third outcome variable - work motivation - the effects of Weberian state structures are remarkably heterogeneous (Figure 4). Public employees recruited via examination are significantly more likely $(+7 \%)$ to be found easier to motivate to work hard relative to those recruited by appointment (H5'). By contrast, job stability does not have a robust effect on work motivation (H6). Public servants in the administrative career (with tenure) are significantly more likely $(+6 \%)$ to be found easier to motivate to work hard than those not incorporated. Yet, the point estimate on work motivation is even larger for those in the process of career incorporation (with similar unobservable characteristics to career servants, but no tenure) $(+7 \%)$. This suggests that unobservable characteristics of tenured public servants - rather than their tenure - account for the effect on work motivation.

Concurrently, the (unsurprising) findings for other characteristics increase confidence in the validity of our results. Respondents are significantly more likely to find fellow public servants recruited by the incumbent party, with university education, and positioned at the technical-professional level as easier to motivate to work hard - relative to high school graduates, opposition party hires, and administrative support-level staff (Figure 4). Gender, by contrast, made no significant difference.

In sum, our results suggest that examinations and tenure are associated with lower corruption (H1 \& H2) and political services (H3 \& H4). Examinations, additionally, enhance work motivation ( $\mathrm{H}^{\prime}$ ), while tenure does not seem to affect work motivation (H6) Except for the effect of tenure on corruption (H2), these results remain robust throughout a range of checks. 


\section{Figure 4. Work Motivation}
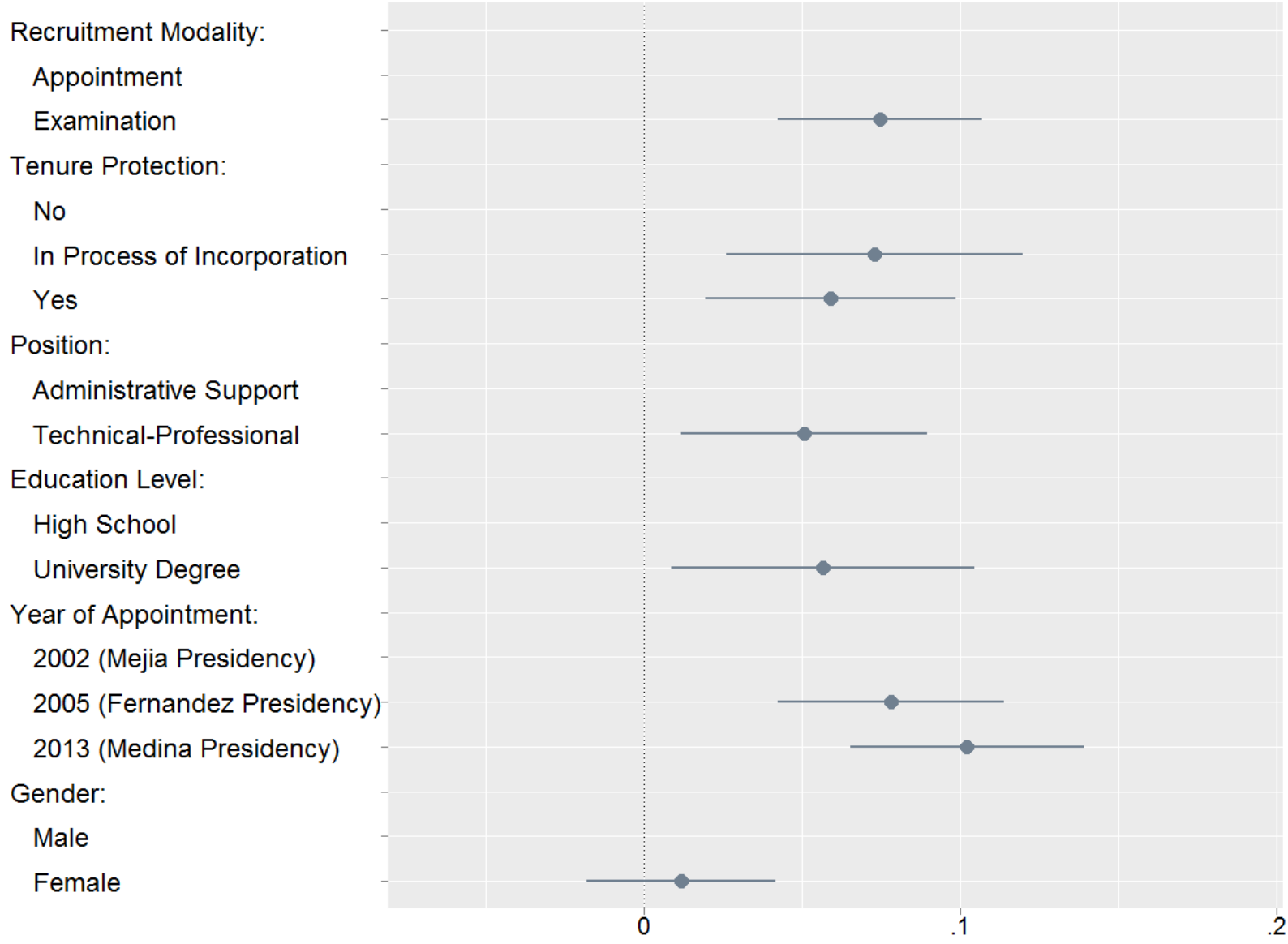

Can Be Convinced to Work Extra Hours To Finish Work

\section{Robustness Checks}

As noted, our sample is representative of public servants in the Dominican Republic in only some respects (gender and age), yet not others. Our respondents have, on average, relative to Dominican public servants, more experience in the public sector, are more educated, and are more likely to hold a technical-professional rank in the bureaucratic hierarchy (Table A.2 in OA). Moreover, many of our respondents are drawn from a single institution (the General Audit Office). Our results could thus merely reflect the perceptions of a group of officials with very specific opinions about the behavior of their fellow bureaucrats. 
To address this concern, we re-estimated our treatment effects for merit examinations and tenure across a series of subgroups in our sample: gender, education, hierarchy, age, years of service, and institution. This yielded 36 subgroup comparisons in total (see Online Appendix C). In 35 of these subgroup comparisons, our core results for merit and tenure remain robust. ${ }^{37}$ Underrepresented subgroups - such as administrative assistants or public servants with fewer years of work experience - do not provide significantly different estimates from the remaining subgroups, neither are results sensitive to the exclusion of the General Audit Office. Although we cannot completely rule out the possibility that a representative survey would have generated different results, our subgroup analyses do not provide any reason to suspect that our results would not hold with a broader sample of Dominican public servants.

At the same time, these responses, of course, need not necessarily be unbiased. Our respondents might wish to shed favorable light on the government (and its administrative reform program); might respond based on effects that they believe merit and tenure should have on bureaucratic behavior; or might tend to see their own group of career servants more favorably. To test for these biases, we conducted several subgroup analyses. With the exception of the effect of tenure on corruption outlined below, our findings remain robust.

To address the first potential bias - respondents strategically favoring or holding more positive views about the government and its reform program - we assess whether the effects of merit and tenure depend on respondent ideological proximity to the government.

\footnotetext{
${ }^{37}$ For our core assertions about the effects of merit and tenure, we either find no statistically significant differences in ATEs between subgroups, or statistically significant differences in which our core results remain significant for each subgroup. A single subgroup comparison - the effect of merit examinations on work motivation in the case of high school-educated respondents - is the exception: it is significantly smaller than for university-educated respondents and overall insignificant. Due to the small number of high school respondents $(\mathrm{N}=15)$, however, we cannot rule out that this is merely a statistical artifact.
} 
If respondents close to the government had a more positive impression of government programs, they would report more favorable effects of merit and tenure. We measure proximity to government with ideological alignment: whether respondents place themselves and the country's President identically on the same 0-10 left right ideological scale (Figure 1 in $0 A ; 39$ percent of respondents are ideologically aligned). ${ }^{38}$ For the effects of examinations on corruption and political services, we do not find statistically significant differences in preferences between ideologically aligned and non-aligned respondents (Figures 2.a and 2.b in $\mathrm{OA}$ ). For the effect of examinations on work motivation, however, there is a statistically significant difference $(\mathrm{p}=0.01)$ (Figure 2.c in $\mathrm{OA}$ ). For respondents aligned with the government, the positive effect of examinations on work motivation is much smaller $+2 \%$ relative to $+11 \%$ ) and insignificant. This speaks against rather than for biases in favor of governmental programs, however. Moreover, it suggests that respondents evaluate the characteristics of profiled public servants relative to their own situation: those aligned with the party in power find (political) appointees easier to motivate. ${ }^{39}$

For the administrative career, by contrast, we can only rule out such biases for work motivation and political services, albeit not corruption. While there are no significant differences for estimates on work motivation and political services, ideologically aligned respondents provide significantly more favorable estimates for career servants when it comes to lower corruption ( $+21 \%$ vs. $+13 \%, \mathrm{p}=0.04)$. We may thus not rule out that (part of) the relationship between job stability and corruption is spurious: respondents closer to

\footnotetext{
${ }^{38}$ We use a measure of ideological distance rather than partisanship, as it appeared less likely to be prone to social desirability biases and to alienate our respondents. Substantively, we know that individuals who place themselves ideologically close to a party are more likely to identify themselves with that party (Lupu, 2015).

${ }^{39}$ Alternatively, respondents closer to the government may place greater trust in government authorities to appoint public servants (without examinations) motivated to work hard.
} 
government may have a favorable impression of the government's administrative career reform program and therefore associate it with lower corruption.

A second potential bias is somewhat subtler: respondents might respond based on prior learning about the effects that merit and tenure should have, given bureaucratic reform goals - rather than workplace experiences. Two pieces of evidence suggest this is not the case. First, respondents do not consistently associate bureaucratic structures with their purported reform goals. For instance, they associate career employees with lower political services, yet not robustly more work motivation (see Figure 2). Second, if estimates were based on learning about reform goals rather than day-to-day experiences with colleagues, estimates should become larger as time passes, with respondents becoming more familiar with official reform goals. Yet, we do not observe this in the data. ${ }^{40}$

Third, our results might be biased due to halo effects: respondents may have more favorable impressions of colleagues who share their characteristics. Yet, we find no evidence of halo effects in a range of cases: male vs. female, governing vs. opposition party recruits, and high school vs. university graduates (see OA). Moreover, administrative career respondents do not consistently favor hypothetical colleagues in the administrative career over those in the process of incorporation (see, e.g., Figure 2); and administrative career employees with more experience in the administrative career - who may have come to identify with it more strongly - do not provide more favorable estimates of career employees (Figures 11.a-11.c in OA).

\footnotetext{
${ }^{40}$ Considering only responses from governing party recruits (to isolate the effect of years of experience from party orientation), we find no differences in the estimates of merit and tenure between respondents with more and less than ten years of experience (the median value of work experience of governing party recruits) (see Figures 11.a -11.c in $\mathrm{OA})$.
} 
Lastly and perhaps most importantly, we compare a further subset of respondents: those who associate the administrative career with greater job stability and those who do not. Respondents were virtually equally split (51\% vs. $49 \%$ ) in this regard (Figure 3 in OA). ${ }^{41,42}$ This is unsurprising: while career servants count on constitutional tenure protections, weak rule of law jeopardizes the value of these protections. We estimate the difference that job stability makes by comparing the estimates of the administrative career between respondents who associate it with enhanced job stability and those who do not. We find no significant differences between these estimates for work motivation and corruption (Figures 3.b. and 3.c in OA). In other words, the perceived effects of the administrative career on work motivation and corruption are not significantly different between respondents who associate the career with greater job stability and those who do not. Job stability by itself thus does not seem to make a significant difference for work motivation or corruption. This confirms the full sample (insignificant) effect for work motivation. At the same time, it suggests that the effect of tenure on corruption identified in Figure 2 is not robust. By contrast, for political services, there is a statistically significant difference (at the $10 \%$ level, $\mathrm{p}=0.08$ ). Respondents who associate the administrative career with greater job stability find it significantly harder to convince hypothetical administrative career servants to go out and campaign $(-11 \%, \mathrm{p}<0.01)$ (Figure 3.a in $\mathrm{OA}$ ). Yet, respondents who do not associate the career with enhanced job stability do not find it statistically significantly harder to convince

\footnotetext{
${ }^{41}$ We measured this by asking separately whether - and how strongly - respondents agree or disagree with the notion that public servants and administrative career servants are protected from arbitrary dismissals. The order of these two questions was randomized so as to avoid priming respondents.

${ }^{42}$ Note that responses in this robustness check are uncorrelated ( $\left.\mathrm{r}=-0.03\right)$ with the ideological alignment of respondents. Respondents thus do not seem to associate the career with enhanced job stability merely to provide a more favorable impression of a governmental reform; else, respondents closer to government should provide more favorable estimates.
} 
colleagues to campaign. This suggests that job stability, in fact, curbs public servants' willingness to campaign.

\section{Discussion and Conclusion}

Bureaucratic behavior in developing countries affects development centrally, yet remains poorly understood. Why do some public servants - yet not others - work hard to deliver public services, misuse state resources, and/or campaign for governing parties? This paper looks at two key Weberian bureaucratic structures - merit and tenure - to explain these conundrums. Weber (1978) had argued that merit recruitment and job stability, among other bureaucratic structures, create an esprit de corps around political neutrality, integrity, and commitment to public service. Our paper finds that Weber was right, but only in part. In our conjoint experiment merit examinations are indeed associated with greater political neutrality (fewer political services), greater work motivation, and greater integrity (lower corruption). By contrast, job stability only delivers on one of Weber's promises: a more politically neutral public service, less willing to help parties with electoral efforts. ${ }^{43}$

Our findings thus provide important nuance to Weber's predictions. While merit examinations enhance the quality of bureaucracy (motivation and lower corruption) and democracy (electoral competition), job stability only enhances the quality of democracy. Focused on single outcome variables, prior studies had overlooked this nuance. This finding also underscores the gains from assessing the effects of bureaucratic structures on the political and administrative behavior of public servants concurrently.

\footnotetext{
${ }^{43}$ In fairness to Weber, Weber theorized about the joint effects of merit, tenure, and other bureaucratic structures, while we are assessing the more disaggregated, marginal effects of merit and tenure.
} 
Importantly, we draw these inferences from the, to our knowledge, first survey experimental test of bureaucratic structures. Prior studies had correlated bureaucratic structures with outcomes such as lower corruption and more political neutrality. However, in light of omitted variable and reverse causality concerns, it remains unclear to what extent those correlations can be interpreted as causal effects. Relying on a conjoint experiment - a method which had previously not been used to study bureaucracy - our study can address these limitations and isolate the effects of bureaucratic structures more robustly.

For the many civil service reform attempts in developing countries (cf. World Bank, 2008), our findings are good news. Changing bureaucratic structures can positively affect bureaucratic behavior in politicized states. Merit trumps tenure in terms of its favorable behavioral effects, enhancing not only the fairness of electoral competition as tenure does, but also bureaucratic performance and integrity. Nonetheless, both merit and tenure remain desirable reforms for developing country bureaucracies. Civil service reformers in developing countries should thus take Weber to heart.

Beyond shedding light on the effects of Weberian bureaucratic structures, our findings have important implications for other scholarly debates. In particular, our paper is the first to show that employees who are appointed - rather than recruited via examinations - are perceived to be more willing to provide political services. We thus provide a microfoundation for studies linking patronage states to incumbency advantages (e.g. Folke et al., 2011). Our paper also provides micro-foundations for studies correlating Weberian state structures with positive development outcomes. Public employees recruited through examinations are more hard working and less corrupt and, as a result, arguably more able to regulate businesses well (cf. Nistotskaya \& Cingolani, 2016); pursue economic growth- 
enhancing policies (cf. Evans \& Rauch, 1999); and deliver higher quality services which reduce corruption and improve health outcomes (cf. Cingolani et al., 2015; Henderson et al., 2007).

This paper also underscores the relevance of demographic characteristics in explaining bureaucratic behavior. Most notably, our study is the first to show that female public servants may not only curb corruption, but also political service provision. This suggests that the recruitment of women into public service in politicized states may have a benefit beyond lower corruption: it may reduce the use of bureaucrats for electoral mobilization. More generally, this finding points to potential gains from expanding the study of gender and good government. A panoply of prior studies has assessed the relationship between gender and corruption. We show that the behavioral effects of gender extend beyond corruption to other good government dimensions such as (lack of) clientelism.

These contributions notwithstanding, our study is, of course, not without limitations. First, our design is unable to disentangle whether merit and tenure shape bureaucratic behavior by changing the types of bureaucrats that join the public sector or by changing the on-the-job behavior of bureaucrats. Both are likely to be at play. Prior studies have associated other bureaucratic reforms - higher salaries (Dal Bó, Finan, \& Rossi, 2013; Krueger, 1988) and more attractive career opportunities (Ashraf, Bandiera, \& Lee, 2014) with higher quality applicants. By changing working conditions and, in the case of merit examinations, employee selection methods, tenure and merit are likely to similarly shape who joins the public administration. By facilitating socialization into a public sector ethos and changing on-the-job incentives, merit and tenure may, however, equally be expected to change the behavior of existing employees. 
Second, our study draws inferences from perceptions of public servants, not their actual behavior. While our respondents interact with colleagues with the characteristics we are studying on a daily basis - and are thus well-placed to provide valid estimates - it remains for future research to determine whether our findings hold with behavioral measures. Not less importantly, our inferences were drawn from studying a single politicized central government. Our 'less likely' case selection procedure gives us some confidence that our findings from the DR might be generalizable to other politicized states. However, whether our findings do in fact travel to other politicized states or beyond that to more professional bureaucracies remains an empirical question. Future research would thus do well to assess the effect of bureaucratic structures on bureaucratic behavior elsewhere. Our study suggests that the conjoint analysis we applied to the study of public administration in this paper can be a powerful method for this purpose - and for the study of bureaucracy atlarge. 


\section{References}

AmericasBarometer. (2014). The Political Culture of Democracy in the Americas, 2014:

Democratic Governance across 10 Years of the AmericasBarometer. Retrieved from Vanderbilt:

http://www.vanderbilt.edu/lapop/ab2014/AB2014 Comparative Report English V3 revised 011315 W.pdf

Andersen, L. B. (2009). What determines the behaviour and performance of health professionals? Public service motivation, professional norms and/or economic incentives. International Review of Administrative Sciences, 75(1), 79-97.

Anderson, C. J., \& Tverdova, Y. V. (2003). Corruption, Political Allegiances, and Attitudes Toward Government in Contemporary Democracies. American Journal of Political Science, 47(1), 91-109.

Ashraf, N., Bandiera, O., \& Lee, S. (2014). Do-gooders and go-getters: career incentives, selection, and performance in public service delivery. STICERD-Economic Organisation and Public Policy Discussion Papers Series, 54.

Becker, G., \& Stigler, G. (1974). Law Enforcement, Malfeasance, and Compensation of Enforcers. The Journal of Legal Studies, 3(1), 1-18.

Blum, J. R. (2014). What Factors Predict How Public Sector Projects Perform? A Review of the World Bank's Public Sector Management Portfolio. Policy Research Working Paper, (WPS6798). 
Botero, J., Ponce, A., \& Shleifer, A. (2013). Education, Complaints, and Accountability. The Journal of Law and Economics, 56(4), 959-996.

Buelens, M., \& Van den Broeck, H. (2007). An Analysis of Differences in Work Motivation between Public and Private Sector Organizations. Public Administration Review, 67(1), 65-74.

Calvo, E., \& Murillo, M. (2004). Who Delivers? Partisan Clients in the Argentine Electoral Market. American Journal of Political Science, 48(4), 742-757.

Carnes, N., \& Lupu, N. (2016). Do Voters Dislike Working-Class Candidates? Voter Biases and the Descriptive Underrepresentation of the Working Class. American Political Science Review, 110(4), 832-844.

Charron, N., Dahlström, C., Fazekas, M., \& Lapuente, V. (2017). Careers, Connections, and Corruption Risks: Investigating the Impact of Bureaucratic Meritocracy on Public Procurement Processes. The Journal of Politics, 79(1), 89-104.

Charron, N., Dahlström, C., \& Lapuente, V. (2012). No law without a state. Journal of Comparative Economics, 40(2), 176-193. Retrieved from http://www.sciencedirect.com/science/article/pii/S0147596711000734

Cingolani, L., Thomsson, K., \& de Crombrugghe, D. (2015). Minding Weber More Than Ever? The Impacts of State Capacity and Bureaucratic Autonomy on Development Goals. World Development, 72, 191-207. 
Coppedge, M., Gerring, J., Lindberg, S., Skaaning, S., Teorell, J., Altman, D., .. Z Zimmerman, V. (2017). V-Dem [Country-Year/Country-Date] Dataset v6.2. Varieties of Democracy ( $V$-Dem) Project.

Dafoe, A., Zhang, B., \& Caughey, D. (2015). Confounding in Survey Experiments. Retrieved from https://www.rochester.edu/college/psc/polmeth/papers/confounding.pdf

Dahlberg, S., Dahlström, C., Sundin, P., \& Teorell, J. (2013). The Quality of Government Expert Survey 2008-2011. Gothenburg: Quality of Government Institute.

Dahlström, C., Lapuente, V., \& Teorell, J. (2012a). The Merit of Meritocratization: Politics, Bureaucracy, and the Institutional Deterrents of Corruption. Political Research Quarterly, 65(3), 656-668.

Dahlström, C., Lapuente, V., \& Teorell, J. (2012b). Public administration around the world. In S. Holmberg \& B. Rothstein (Eds.), Good Government: The Relevance of Political Science (pp. 40-67). Cheltenham: Edward Elgar.

Dal Bó, E., Finan, F., \& Rossi, M. (2013). Strengthening State Capabilities: The Role of Financial Incentives in the Call to Public Service*. The Quarterly Journal of Economics, 128(3), 1169-1218.

Davis, C. L., Camp, R. A., \& Coleman, K. M. (2004). The Influence of Party Systems on Citizens' Perceptions of Corruption and Electoral Response in Latin America. Comparative Political Studies, 37(6), 677-703. 
Dumas, V., \& Lafuente, M. (2015). Gestion de los Recursos Humanos del Estado. In J. Prat \& J. Beverinotti (Eds.), Una Mirada al Gasto Social en Centroamerica, Panama y Republica Dominicana (pp. 27-65). Washington DC: Inter-American Development Bank.

Espinal, R., Morgan, J., \& Seligson, M. (2012). Cultura política de la democracia en República Dominicana y en las Américas. Retrieved from http://www.vanderbilt.edu/lapop/dr/DR Country Report 2012 V3 revised W.pdf

Evans, P., \& Rauch, J. (1999). Bureaucracy and Growth: A Cross-National Analysis of the Effects of "Weberian" State Structure on Economic Growth. American Sociological Review, 64(5), 748-765.

Finan, F., \& Schechter, L. (2012). Vote-Buying and Reciprocity. Econometrica, 80(2), 863881.

Folke, O., Hirano, S., \& Snyder, J. (2011). Patronage and Elections in U.S. States. American Political Science Review, 105(03), 567-585.

Frank, B., Lambsdorff, G. J., \& Boehm, F. (2011). Gender and Corruption: Lessons from Laboratory Corruption Experiments. The European Journal of Development Research, 23(1), 59-71.

Fukuyama, F. (2014). Political Order and Political Decay: From the Industrial Revolution to the Globalization of Democracy. London: Profile Books. 
Gallo, N., \& Lewis, D. E. (2012). The Consequences of Presidential Patronage for Federal Agency Performance. Journal of Public Administration Research and Theory, 22(2), 219-243.

Geddes, B. (1996). Politician's Dilemma: Building State Capacity in Latin America. Berkeley: University of California Press.

Gerring, J., \& Thacker, S. (2004). Political Institutions and Corruption: The Role of Unitarism and Parliamentarism. British Journal of Political Science, 34, 295-330.

Gingerich, D. (2013a). Governance Indicators and the Level of Analysis Problem: Empirical Findings from South America. British Journal of Political Science, 43(3), 505-540.

Gingerich, D. (2013b). Political Institutions and Party-Directed Corruption in South America: Stealing for the Team. Cambridge: Cambridge University Press.

Grindle, M. (2012). Jobs for the Boys: Patronage and the State in Comparative Perspective Cambridge: Harvard University Press.

Grzymala-Busse, A. (2007). Rebuilding Leviathan: Party Competition and State Exploitation in Post-Communist Democracies. Cambridge: Cambridge University Press.

Hainmueller, J., Hangartner, D., \& Yamamoto, T. (2015). Validating vignette and conjoint survey experiments against real-world behavior. Proceedings of the National Academy of Sciences, 112(8), 2395-2400. 
Hainmueller, J., \& Hopkins, D. J. (2015). The Hidden American Immigration Consensus: A Conjoint Analysis of Attitudes toward Immigrants. American Journal of Political Science, 59(3), 529-548.

Hainmueller, J., Hopkins, D. J., \& Yamamoto, T. (2014). Causal Inference in Conjoint Analysis: Understanding Multidimensional Choices via Stated Preference Experiments. Political Analysis, 22(1), 1-30.

Henderson, J., Hulme, D., Jalilian, H., \& Phillips, R. (2007). Bureaucratic Effects: 'Weberian' State Agencies and Poverty Reduction. Sociology, 41(3), 515-532.

Holley, J. (1977). Tenure and Research Productivity. Research in Higher Education, 6(2), 181-192.

Houston, D. (2014). Public Service Motivation in the Post-Communist State. Public Administration, 92(4), 843-860.

James, O., Jilke, S., \& Van Ryzin, G. (2017). Experiments in Public Management Research: Challenges and Contributions. Cambridge: Cambridge University Press.

Johnson, R., \& Orme, B. (1996). How Many Questions Should You Ask in Choice-Based Conjoint Studies? RESEARCH PAPER SERIES. Retrieved from https://www.sawtoothsoftware.com/download/techpap/howmanyq.pdf

Kaufmann, D., Mastruzzi, M., \& Zavaleta, D. (2003). Sustained Macroeconomic Reforms, Tepid Growth: A Governance Puzzle in Bolivia? Retrieved from https://ideas.repec.org/p/wpa/wuwpdc/0308003.html 
Kim, S., Vandenabeele, W., Wright, B. E., Andersen, L. B., Cerase, F. P., Christensen, R. K., ... De Vivo, P. (2013). Investigating the Structure and Meaning of Public Service Motivation across Populations: Developing an International Instrument and Addressing Issues of Measurement Invariance. Journal of Public Administration Research and Theory, 23(1), 79-102.

Kitschelt, H. (2014). Democratic Accountability and Linkages Project. 2008-9 Dataset. Retrieved from https://sites.duke.edu/democracylinkage/data/

Kitschelt, H., \& Kselman, D. (2013). Economic Development, Democratic Experience, and Political Parties' Linkage Strategies. Comparative Political Studies, 46(11), 14531484.

Kitschelt, H., \& Wilkinson, S. (2007a). Citizen-politician linkages: an introduction. In H. Kitschelt \& S. Wilkinson (Eds.), Patrons, Clients and Policies - Patterns of Democratic Accountability and Political Competition (pp. 1-49). Cambridge: Cambridge University Press.

Kitschelt, H., \& Wilkinson, S. (2007b). Patrons, Clients and Policies: Patterns of Democratic Accountability and Political Competition. Cambridge: Cambridge University Press.

Kopecký, P., Mair, P., \& Spirova, M. (2012). Party Patronage and Party Government in European Democracies. Oxford: Oxford University Press. 
Kopecky, P., Meyer Sahling, J.-H., Panizza, F., Scherlis, G., Schuster, C., \& Spirova, M. (2016). Party patronage in contemporary democracies: Results from an expert survey in 22 countries from five regions. European Journal of Political Research, 55(2), 416-431.

Krueger, A. (1988). The Determinants of Queues for Federal Jobs. ILR Review, 41(4), 567581.

Larreguy, H., Olea, C., \& Querubin, P. (2014). The Role of Labor Unions as Political Machines: Evidence from the Case of the Mexican Teacher's Union. Harvard University. Typescript.

Lawson, C., \& Greene, K. F. (2014). Making Clientelism Work: How Norms of Reciprocity Increase Voter Compliance. Comparative Politics, 47(1), 61-77.

Lewis, D. E. (2007). Testing Pendleton's Premise: Do Political Appointees Make Worse Bureaucrats? Journal of Politics, 69(4), 1073-1088.

Lindstedt, C., \& Naurin, D. (2010). Transparency is not Enough: Making Transparency Effective in Reducing Corruption. International Political Science Review, 31(3), 301322.

Manning, N. (2001). The Legacy of the New Public Management in Developing Countries. International Review of Administrative Sciences, 67(2), 297-312.

Meyer-Sahling, J.-H., \& Mikkelsen, K. S. (2016). Civil Service Laws, Merit, Politicization, and Corruption: The Perspective of Public Officials from five East European Countries. Public Administration, 94(4), 1105-1123. 
Moe, T. (1985). The politicized presidency. In J. Chubb \& P. Peterson (Eds.), The new direction in American politics (pp. 235-271). Washington, DC: Brookings Institution.

Montinola, G., \& Jackman, R. (2002). Sources of Corruption: A Cross-Country Study. British Journal of Political Science, 32(1), 147-170.

Morris, S., \& Klesner, J. (2010). Corruption and Trust: Theoretical Considerations and Evidence From Mexico. Comparative Political Studies, 43(10), 1258-1285.

Murillo, M. V., Oliveros, V., \& Vaishnav, M. (2010). Electoral Revolution or Democratic Alternation? . Latin American Research Review, 45(3), 87-114.

Neshkova, M. I., \& Kostadinova, T. (2012). The Effectiveness of Administrative Reform in New Democracies. Public Administration Review, 72(3), 324-333.

Nistotskaya, M., \& Cingolani, L. (2016). Bureaucratic Structure, Regulatory Quality, and Entrepreneurship in a Comparative Perspective: Cross-Sectional and Panel Data Evidence. Journal of Public Administration Research and Theory, 26(3), 519-534.

O'Dwyer, C. (2006). Runaway State-Building: Patronage Politics and Democratic Development. Baltimore: Johns Hopkins University Press.

Oliveros, V. (2016a). Making it Personal: Clientelism, Favors, and the Personalization of Public Administration in Argentina. Comparative Politics, 48(3), 373-391.

Oliveros, V. (2016b). A Working Machine: Patronage Jobs and Political Services in Argentina. Tulane University, Unpublished manuscript. 
Participación Ciudadana. (2008). Primer Informe sobre la Observación de las Elecciones Presidenciales 2008. Retrieved from https://de.slideshare.net/opd/1-er-informede-observacin-electoral-elecciones-presidenciales-2008

Peisakhin, L. (2012). Transparency and Corruption: Evidence from India. The Journal of Law \& Economics, 55(1), 129-149.

Rauch, J. (1995). Bureaucracy, Infrastructure, and Economic Growth: Evidence from U.S. Cities During the Progressive Era. The American Economic Review, 85(4), 968-979.

Rauch, J., \& Evans, P. (2000). Bureaucratic structure and bureaucratic performance in less developed countries. Journal of Public Economics, 75(1), 49-71.

Robinson, J., \& Verdier, T. (2013). The Political Economy of Clientelism. The Scandinavian Journal of Economics, 115(2), 260-291.

Rose-Ackerman, S. (1999). Corruption and Government: Causes, Consequences, and Reform. Cambridge: Cambridge University Press.

Rose-Ackerman, S. (2004). Governance and corruption. In B. Lomborg (Ed.), Global Crises, Global Solutions (pp. 301-362). Cambridge: Cambridge University Press.

Rothstein, B. (2011). The Quality of Government: Corruption, Social Trust, and Inequality in International Perspective. Chicago: University of Chicago Press.

Schuster, C. (2014). Strategies to Professionalize the Civil Service - Lessons from the Dominican Republic. Washington DC: Inter-American Development Bank. 
Schuster, C. (2016a). What Causes Patronage Reform? It Depends on the Type of Civil Service Reform. Public Administration, 94(4), 1094-1104.

Schuster, C. (2016b). When the Victor Cannot Claim the Spoils: Institutional Incentives for Professionalizing Patronage States (Vol. IDB-WP-667). Washington DC: InterAmerican Development Bank.

Singer, M. (2012). Electoral Politics in the Dominican Republic: Low Levels of Programmatic Competition. Retrieved from http://ec2-174-129-218-71.compute1.amazonaws.com/development/upload/dominican republic.pdf

Stokes, S. (2007). Political Clientelism. In C. Boix \& S. Stokes (Eds.), The Oxford Handbook of Comparative Politics (pp. 604-627). Oxford: Oxford University Press.

Stokes, S., Dunning, T., Nazareno, M., \& Brusco, V. (2013). Brokers, Voters, and Clientelism: The Puzzle of Distributive Politics: Cambridge University Press.

Strezhnev, A., Berwick, E., Hainmueller, J., Hopkins, D., \& Yamamoto, T. (2016). AMCE Estimator for Conjoint Experiments. Retrieved from https://cran.rproject.org/web/packages/cjoint/cjoint.pdf

Swamy, A., Knack, S., Lee, Y., \& Azfar, O. (2001). Gender and corruption. Journal of Development Economics, 64(1), 25-55.

Tendler, J. (1997). Good Government in the Tropics. Baltimore: Johns Hopkins University Press. 
Torgler, B., \& Valev, N. T. (2010). Gender and public attitudes toward corruption and tax evasion. Contemporary Economic Policy, 28(4), 554-568.

Treisman, D. (2007). What Have We Learned About the Causes of Corruption from Ten Years of Cross-National Empirical Research? Annual Review of Political Science, 10, 211-244.

UNDP. (2014). Motivation of Public Service Officials: Insights for Practitioners. Retrieved from http://www.undp.org/content/dam/undp/library/capacitydevelopment/English/Singapore\%20Centre/GPCSE PSM.pdf?download

United States Office of Personnel Management. (2016). Federal Employee Viewpoint Survey Results: Employees Influencing Change. Retrieved from https://www.fedview.opm.gov/2015FILES/2015 FEVS Gwide Final Report.pdf

Weber, M. (1978). Economy and Society: An Outline of Interpretive Sociology. Berkeley and Los Angeles: University of California Press.

Weitz-Shapiro, R. (2014). Curbing Clientelism in Argentina: Politics, Poverty, and Social Policy. Cambridge: Cambridge University Press.

Wiesehomeier, N., \& Benoit, K. (2009). Presidents, Parties, and Policy Competition. The Journal of Politics, 71(4), 1435-1447.

Willis-Shattuck, M., Bidwell, P., Thomas, S., Wyness, L., Blaauw, D., \& Ditlopo, P. (2008). Motivation and retention of health workers in developing countries: a systematic review. BMC Health Services Research, 8(1), 1-8. 
Winters, M. S., \& Weitz-Shapiro, R. (2013). Lacking Information or Condoning Corruption: When Do Voters Support Corrupt Politicians? Comparative Politics, 45(4), 418-436.

World Bank. (2008). Public Sector Reform: What Works and Why? - An IEG Evaluation of World Bank Support. Washington DC: World Bank.

Wright, B. (2004). The Role of Work Context in Work Motivation: A Public Sector Application of Goal and Social Cognitive Theories. Journal of Public Administration Research and Theory, 14(1), 59-78.

Zarazaga, R. (2014). Brokers Beyond Clientelism: A New Perspective Through the Argentine Case. Latin American Politics and Society, 56(3), 23-45. 